\title{
METODE USHUL FIQIH HASAN HANAFI
}

\author{
Moh Sholehuddin \\ Kementrian Agama Sidoarjo \\ Email:m.sholehuddin@yahoo.com
}

\begin{abstract}
Abstrak
Ushul Figh reconstruction is one of Hassan Hanafi renewal projects branch. To him, ushul Figh is 'revealed' science that means 'something' which is revealed from Allah to human beings. It is a science which is sent down-oriented for human beings' goodness. Ushul figh which is constructed by Hasan Hanafi is different from the previous works on ushul figh in four aspects. First, object of discussion is put systematically from mashadir arba' an to adillah syariyyah the ahkam syar'iyah. Second, there are orientation and tendency to give wider space for human being's duty and potential in understanding and implementing God's revelation in real life. Third, hasan hanafi's work gives idioms articulating humanbeing's potential as the practice of second conclusion. Fourth, the work is also deductive explaining general theories and free from mentioning law examples as description for understanding theories towards text content.

Rekonstruksi ushul fiqih adalah salah satu cabang dari proyek pembaruan tradisi Hasan Hanafi. Baginya, ushul fiqih adalah ilmu 'tanzil' yaitu 'sesuatu' yang berasal dari Allah untuk manusia. Ilmu yang berorientasi ke bawah, kepada mashlahah manusia. Ushul fiqih yang dicoba oleh Hasan Hanafi untuk direkonstruksi minimal tampak perbedaannya dengan ushul fiqih karya para ushuli terdahulu pada empat aspek. Pertama, resistematisasi objek pembahasan. Dimulai dari mashadir arba'an, lalu adillah syariyyah kemudian ahkam syar'iyah. Kedua, adanya orientasi dan kecenderungan memberi ruang lebar bagi pentransparanan bagi tugas dan potensi manusia dalam menjemput misi wahyu dan pengimplementasiannya dalam kehidupan manusia yang riil. Ketiga, memberikan idiomidiom (redaksi, ta'bir) yang mengartikulasikan potensi kemanusiaan sebagai tindak lanjut dari kesimpulan nomor dua di atas. Keempat, bersifat deduktif, menjelaskan teori-teori yang bersifat general dan sepi dari penyebutan contoh-contoh hukum sebagai deskripsi bagi teori-teori pemahaman terhadap isi teks
\end{abstract}

Kata Kunci: Turats, Tajdid, Ushul Fiqih, Mashlahah

Kajian Islam mengalami kemandegan serius. Itulah kekhawatiran juga keprihatinan yang dirasakan oleh banyak ulama' dan cendekiawan muslim. Kemandegan kajian Islam berarti kemandegan ilmu-ilmu Islam, padahal karakter ilmu adalah dinamis, terus mengalami perkembangan. Sangat berbeda dengan yang terjadi di era kerajaan Abbasiyah pada abad 8- $11 \mathrm{M}$ silam. Di ma- sa silam tersebut, masa keemasan Islam, terjadi perkembangan ilmu yang sangat dinamis. Tumbuh berbagai macam disiplin ilmu. Dalam satu disiplin ilmu terjadi proses dialektika, kritik, sintesis bahkan dekonstruksi sehingga muncul teori baru. Contohnya adalah munculnya karya-karya filosofis dalam Islam yang ditulis oleh alKindi dan al-Farabi yang menjadi bahan 
kajian dan kritik al-Ghazali sehingga lahir karya Tahâfut al-Falâsifah (Kerancauan Para Filosof). ${ }^{1}$ Karya al-Ghazali tersebut sangat populer dan mempengaruhi pandangan hidup kaum muslim saat itu. Beberapa puluh tahun pasca wafatnya al-Ghazali (1111 M), karya al-Ghazali tersebut dikritisi oleh Ibn Rusyd melalui kitabnya yang berjudul Tahâfut al-Tahâfut. Karya filsafat Ibnu Rusyd tersebut sengaja dikarang untuk menolak karya al-Ghazali. Bahkan Ibnu Rusyd kemudian menulis satu kitab khusus yang menjelaskan tentang relasi harmonis antara syariah dengan filsafat yaitu Fash al-Maqâl fi Hukmi mâ bayna al-Hikmah wa al-Syarî́at min al-Ittishâl. ${ }^{2}$

Hasan Hanafi, cendekiawan muslim asal Mesir yang mencurahkan waktu dan tenaganya untuk mengkaji Islam dengan pendekatan dan teori sosial modern dari Perancis, mengatakan bahwa mayoritas kajian Islam dewasa ini pada faktanya merupakan repetisi (tikrâr) terhadap hasil kajian ulama atau cendekiawan terdahulu. Penukilan terhadap isi literatur-literatur terdahulu tanpa ada kritik, pengembangan atau penolakan. Penulisan kitab matan, syarah atau hâsyiyah, pada satu sisi, bermanfaat untuk penyederhanaan ilmu bagi pelajar pemula dan menengah. Pada sisi lain, berakibat negatif yaitu menciptakan repitisirepetisi, tidak mendorong lahirnya kreatifitas dan orisinilitas gagasan.

Ulil Abshar Abdallah, cendekiawan muda Indonesia, mengatakan, kemandegan kajian Islam di Indonesia hampir merata di semua cabang ilmu pengetahuan. Cabang-cabang keilmuan 'ortodoks' yang mestinya menjadi kajian unggulan pun tidak mengalami perkembangan yang signifikan. Kajian fiqih, ushul fiqih, atau tafsir juga tidak ada terobosan yang penting baik di pesantren maupun di perguruan tinggi. Setelah generasi al-Imam Nawawi Banten dari abad

\footnotetext{
${ }^{1}$ Nurcholish Madjid, Khazanah Intelektual Islam (Bandung: Bulan Bintang, 1984), h. 25-39

${ }^{2}$ Teks asli Fash al-Maqâl f $\checkmark i$ Hukmi ma bayna al-Hikmat al-Syarî'at min al-Ittishâl dapat dilihat dalam Averroes, Le Livre Du Discours Decisif (Paris: Flammarion, 1996)
}

19 M hingga saat ini belum pernah ada karya penting yang ditulis orang Indonesia baik di bidang fiqih maupun ushul fiqih. Ada geliat yang cukup menarik di bidang tafsir. Sekurang-kurangnya ada dua tafsir penting yang ditulis oleh ulama' Indonesia yaitu tafsir al-Azhar Hamka dan al-Mishbâh Quraish Shihab. ${ }^{3}$

Mendinamisir perkembangan ilmu itu penting, bukan untuk 'gagah-gagahan', mencari sisi kontrofersial atau untuk menperoleh popularitas. Ada motivasi yang lebih luhur dari semua itu yaitu motivasi agar ilmu-ilmu yang diformulasikan itu mampu memberi kontribusi, manfaat dan maslahah bagi kehidupan manusia. Hidup itu dinamis, selalu berubah dari waktu ke waktu. Islam dan ilmu-ilmu yang terkait dengannya; ilmu aqidah (teologi), ilmu syari'ah dan akhlaq harus mampu memecahkan problematika mutakhir kehidupan manusia.

Ketika kehidupan duniawi manusia secara global dihadapkan pada problem demokrasi, hak asasi manusia, dan hukum internasional, maka ajaran Islam harus mampu memberi jawaban yang benar dan membawa maslahah terhadap tiga problematika modern itu. Karena itulah, kemudian tampil antara lain Abdullah Ahmed an-Na'îm yang menelaah ulang konsep ajaran Islam, terutama bidang ulûm al-Qur'ân yaitu konsep tentang nasakhmansukh, ayat Makkiyah-Madaniyah dan bidang fiqih untuk merespon zaman dengan cerdas sehingga umat Islam mampu hidup dengan saleh, maju dan modern. ${ }^{4}$ Ajaran Islam meskipun terhimpun dalam dua aspek seperti pendapat Mahmod Syaltut yaitu aqidah dan syari' ah saja, atau tiga aspek yaitu iman, Islam dan ihksan seperti kandungan hadis itu sangat universal. Di sisi lain, kehidupan manusia itu sangat kompleks, melibatkan politik, sosial, ekonomi, dan budaya.

\footnotetext{
${ }^{3}$ Ulil Abshar Abdalla. Kenapa Kajian Islam Mandeg? .( www.islamlib.com. (Diakses 30 Mei 2006).

${ }^{4}$ Abdullah Ahmed an-Naim, Toward an Islamic Reformation: Civil Liberties, Human Right and International Law (New York: Syracuse University Press, 1946), h. $47-48,52-56$.
} 
Menjaga orisinilitas dan pengembangan ajaran Islam yang meliputi tiga aspek di atas dalam kehidupan manusia, dalam kehidupan zaman yang terus berkembang sehingga kehidupan manusia itu tetap Islami, makmur, modern dan penuh manfaat di zamannya, adalah tugas yang dlârury (mendesak).

Hasan Hanafi adalah sosok cendekiawan muslim yang telah memberi contoh yang baik kepada kita. Dia adalah cendekiawan multi dimensi. Dia menyamudera dalam teologi dan aktualisasi nilai-nilai teologi dalam kehidupan modern. Itu semua ditulis oleh Hasan Hanafi dalam kitab monumentalnya berjudul Min al-Aqîdah ila al-Tsurah yang terbit dalam lima volume berbahasa Arab.

Dalam bidang kalam, Hasan Hanafi memaparkan filsafat Timur dan Barat, dan hikmah apa yang dapat diambil umat Islam dari dua filsafat itu demi kemajuan hidup. Hal itu dipaparkan Hasan Hanafi dalam falsafah al-Hadlârah: Min al-Naql ila al-Ibdâ'. Dalam bidang tasawwuf, Hasan Hanafi menulis al-Manhaj al-Shûfi: Min al-Fanâ' ila al-Baqấ, untuk konsep tasawwuf dan revitalisasinya bagi kemajuan hidup manusia. Khusus pada bidang hukum, terutama ushul fiqih, Hasan Hanafi menulis al-Manhaj al-Ushuli: Min alNash ila al-Wâqi', satu kitab besar tentang ushul fiqih tetapi terdiri atas dua volume. Pertama, bersub judul Takwîn al-Nash, dan kedua bersub judul Binyat al-Nash. ${ }^{5}$

Berpijak pada keterangan-keterangan di atas, maka tulisan ini akan memperkenalkan kepada para pembaca tentang upaya-upaya intelektual Hasan Hanafi dalam memahami dan menata ulang ushul fiqih agar ilmu tersebut, diharapkan lebih berperan dalam memberi kontribusi bagi kemajuan hidup umat di era sekarang dan selanjutnya.

\footnotetext{
${ }^{5}$ Hasan Hanafi, al-Turâts wa al-Tajdîd (Beirut: alMuassasah al-Jâmi'ah li al-Dirâsât wa al-Nasyr wa altawzî', 1992), h. 176-178
}

\section{Seputar Biografi dan Karya-Karya Intelektual ${ }^{6}$}

Hassan Hanafi adalah guru besar pada fakultas filsafat Universitas Kairo. Ia lahir pada 13 Februari 1935 di Kairo, di dekat Benteng Salahuddin, daerah perkampungan al-Azhar. Kota ini merupakan tempat bertemunya para mahasiswa muslim dari seluruh dunia yang ingin belajar, terutama di Universitas al-Azhar. Meskipun lingkungan sosialnya dapat dikatakan tidak terlalu mendukung, tradisi keilmuan berkembang di sana sejak lama. Secara historis dan kultural, kota Mesir memang telah dipengaruhi peradaban-peradaban besar sejak masa Fir'aun, Romawi, Bizantium, Arab, Mamluk dan Turki, bahkan sampai dengan Eropa moderen. Hal ini menunjukkan bahwa Mesir, terutama kota Kairo, mempunyai arti penting bagi perkembangan awal tradisi keilmuan Hassan Hanafi.

Masa kecil Hanafi berhadapan dengan kenyataan-kenyataan hidup di bawah penjajahan dan dominasi pengaruh bangsa asing. Kenyataan itu membangkitkan sikap patriotik dan nasionalismenya, sehingga tidak heran meskipun masih berusia 13 tahun ia telah mendaftarkan diri untuk menjadi sukarelawan perang melawan Israel pada tahun 1948. la ditolak oleh Pemuda Muslimin karena dianggap usianya masih terlalu muda. Di samping itu ia juga dianggap bukan berasal dari kelompok Pemuda Muslimin. Ia kecewa dan segera menyadari bahwa di Mesir saat itu telah terjadi problem persatuan dan perpecahan.

Ketika masih duduk di bangku SMA, tepatnya pada tahun 1951, Hanafi menyaksikan sendiri bagaimana tentara Inggris membantai para syuhadâ' di Terusan Suez. Bersama-sama dengan para mahasiswa ia mengabdikan diri untuk membantu gerakan revolusi yang telah dimulai pada akhir tahun 1940-an hingga revolusi itu meletus

${ }^{6}$ Semua informasi tentang biografi dan karya intelektual Hasan Hanafi diambil dari Ridwan Ahmad Hasan . Pemikiran Hasan Hanafi : Studi Historis Kritis Gagasan Reaktualisasi Tradisi Keilmuan. (http:// en.wikipedia.org/wiki/Hasan_Hanafi, 1997). 
pada tahun 1952. Atas saran anggotaanggota Pemuda Muslimin, pada tahun ini pula ia tertarik untuk memasuki organisasi Ikhwanul Muslimin. Akan tetapi, di tubuh Ikhwan-pun terjadi perdebatan yang sama dengan apayang terjadidi Pemuda Muslimin. Kemudian Hanafi kembali disarankan oleh para anggota Ikhwan untuk bergabung dalam organisasi Mesir Muda. Ternyata keadaan di dalam tubuh Mesir Muda sama dengan kedua organisasi sebelumnya. Hal ini mengakibatkan ketidakpuasan Hanafi atas cara berpikir kalangan muda Islam yang terkotak-kotak. Kekecewaan ini menyebabkan ia memutuskan beralih konsentrasi untuk mendalami pemikiranpemikiran keagamaan, revolusi, dan perubahan sosial. Ini juga yang menyebabkan ia lebih tertarik pada pemikiran-pemikiran Sayyid Qutb, seperti tentang prinsip-prinsip keadilan sosial dalam Islam.

Sejak tahun 1952 sampai dengan 1956 Hanafi belajar di Universitas Kairo untuk mendalami bidang filsafat. Di dalam periode ini ia merasakan situasi yang paling buruk di Mesir. Pada tahun 1954 misalnya, terjadi pertentangan keras antara Ikhwan dengan gerakan revolusi. Hanafi berada pada pihak Muhammad Najib yang berhadapan dengan Nasser, karena baginya Najib memiliki komitmen dan visi keislaman yang jelas. Kejadian-kejadian yang ia alami pada masa ini, terutama yang ia hadapi di kampus, membuatnya bangkit menjadi seorang pemikir, pembaharu, dan reformis. Keprihatinan yang muncul saat itu adalah mengapa umat Islam selalu dapat dikalahkan, dan konflik internal terus terjadi.

Tahun-tahun berikutnya, Hanafi berkesempatan untuk belajar di Universitas Sorborne; Perancis, pada tahun 1956 sampai 1966. Di sini ia memperoleh lingkungan yang kondusif untuk mencari jawaban atas persoalan-persoalan mendasar yang sedang dihadapi oleh negerinya dan sekaligus merumuskan jawaban-jawabannya. Di Perancis inilah ia dilatih untuk berpikir secara metodologis melalui kuliah-kuliah maupun ba- caan-bacaan atau karya-karya orientalis. Ia sempatbelajar pada seorang reformis Katolik, Jean Gitton; tentang metodologi berpikir, pembaharuan, dan sejarah filsafat. Ia belajar fenomenologi dari Paul Ricouer, analisis kesadaran dari Husserl, dan bimbingan penulisan tentang pembaharuan Ushul Fikih dari Profesor Masinion. Semangat Hanafi untuk mengembangkan tulisan-tulisannya tentang pembaharuan pemikiran Islam semakin tinggi sejak ia pulang dari Perancis pada tahun 1966. Akan tetapi, kekalahan Mesir dalam perang melawan Israel tahun 1967 telah mengubah niatnya itu. la kemudian ikut serta dengan rakyat berjuang dan membangun kembali semangat nasionalisme mereka. Pada sisi lain, untuk menunjang perjuangannya itu, Hanafi juga mulai memanfaatkan pengetahuan-pengetahuan akademis yang telah ia peroleh dengan memanfaatkan media massa sebagai corong perjuangannya. Ia menulis banyak artikel untuk menanggapi masalah-masalah aktual dan melacak faktor kelemahan umat Islam.

Di waktu-waktu luangnya, Hanafi mengajar di Universitas Kairo dan beberapa universitas di luar negeri. Ia sempat menjadi profesor tamu di Perancis (1969) dan Belgia (1970). Kemudian antara tahun 1971 sampai 1975 ia mengajar di Universitas Temple, Amerika Serikat. Kepergiannya ke Amerika, sesungguhnyaberawaldariadanyakeberatan pemerintah terhadap aktivitasnya di Mesir, sehingga ia diberikan dua pilihan apakah ia akan tetap meneruskan aktivitasnya itu atau pergi ke Amerika Serikat. Pada kenyataannya, aktivitasnya yang baru di Amerika memberinya kesempatan untuk banyak menulis tentang dialog antaragama dengan revolusi. Baru setelah kembali dari Amerika ia mulai menulis tentang pembaruan pemikiran Islam. Ia kemudian memulai penulisan buku al-Turats wa al-Tajdid. Karya ini, saat itu, belum sempat ia selesaikan karena ia dihadapkan pada gerakan antipemerintah Anwar Sadat yang pro-barat dan "berkolaborasi" dengan Israel. la terpaksa harus terlibat untuk membantu menjernihkan 
situasi melalui ulisan-tulisannya yang berlangsung antara tahun 1976 hingga 1981. Tulisan-tulisannya itulah yang kemudian tersusun menjadi buku al- Din wa aI- Tsaurah. Sementara itu, dari tahun 1980 sampai 1983, ia menjadi profesor tamu di Universitas Tokyo, tahun 1985 di Emirat Arab. Ia pun diminta untuk merancang berdirinya Universitas Fes ketika ia mengajar di sana pada tahun-tahun 1983-1984. Hanafi berkali-kali mengunjungi negara-negara Belanda, Swedia, Portugal, Spanyol, Perancis, Jepang, India, Indonesia, Sudan, Saudi Arabia dan sebagainya antara tahun 1980-1987. Pengalaman pertemuannya dengan para pemikir besar di negara-negara tersebut telah menambah wawasannya untuk semakin tajam memahami persoalanpersoalan yang dihadapi oleh dunia Islam.

Maka, dari pengalaman hidup yang ia peroleh sejak masih remaja membuat ia memiliki perhatian yang begitu besar terhadap persoalan umat Islam. Karena itu, meskipun tidak secara sepenuhnya mengabdikan diri untuk sebuah pergerakan tertentu, ia pun banyak terlibat langsung dalam kegiatan-kegiatan pergerakan-pergerakan yang ada di Mesir. Sedangkan pengalamannya dalam bidang akademis dan intelektual, baik secara formal maupun tidak, dan pertemuannya dengan para pemikir besar dunia semakin mempertajam analisis dan pemikirannya sehingga mendorong hasratnya untuk terus menulis dan mengembangkan pemikiran-pemikiran baru untuk membantu menyelesaikan persoalan-persolan besar umat Islam.

\section{Perkembangan Pemikiran dan Karya- Karyanya}

Untuk memudahkan uraian pada bagian ini, kita dapat mengklasifikasikan karyakarya Hanafi dalam tiga periode, seperti halnya yang dilakukan oleh beberapa penulis yang telah lebih dulu mengkaji pemikiran tokoh ini: Periode pertama berlangsung pada tahun-tahun 1960-an, periode kedua pada tahun-tahun 1970-an, dan periode ketiga dari tahun-tahun 1980-an sampai dengan 1990-an.

Pada awal dasawarsa 1960-an pemikiran Hanafi dipengaruhi oleh faham-faham dominan yang berkembang di Mesir, yaitu nasionalistik-sosialistik populistik yang juga dirumuskan sebagai ideologi Pan Arabisme, dan oleh situasi nasional yang kurang menguntungkan setelah kekalahan Mesir dalam perang melawan Israel pada tahun 1967. Pada awal dasawarsa ini pula (19561966), sebagaimana telah dikemukakan, Hanafi sedang berada dalam masa-masa belajar di Perancis. Di Perancis inilah, Hanafi lebih banyak lagi menekuni bidang-bidang filsafat dan ilmu sosial dalam kaitannya dengan hasrat dan usahanya untuk melakukan rekonstruksi pemikiran Islam.

Untuk tujuan rekonstruksi itu, selama berada di Perancis ia mengadakan penelitian tentang, terutama, metode interpretasi sebagai upaya pembaharuan bidang ushul fikih (teori hukum Islam, Islamic legal theory) dan tentang fenomenologi sebagai metode untuk memahami agama dalam konteks realitas kontemporer. Penelitian itu sekaligus merupakan upayanya untuk meraih gelar doktor pada Universitas Sorbonne (Perancis), dan ia berhasil menulis disertasi yang berjudul Essai sur la Methode d' Exegese (Esai tentang Metode Penafsiran). Karya setebal 900 halaman itu memperoleh penghargaan sebagai karya iliniah terbaik di Mesir pada tahun 1961. Dalam karyanya itu jelas Hanafi berupaya menghadapkan ilmu ushul fikih pada mazhab filsafat fenomenologi Edmund Husserl.

Pada fase awal pemikirannya itu, tulisantulisan Hanafi masih bersifat ilmiah murni. Baru pada akhir dasawarsa itu ia mulai berbicara tentang keharusan Islam untuk mengembangkan wawasan kehidupan yang progresif dan berdimensi pembebasan (taharrur, liberation). Ia mensyaratkan fungsi pembebasan jika memang itu yang diinginkan Islam agar dapat membawa masyarakat pada kebebasan dan keadilan, 
khususnya keadilan sosial, sebagai ukuran utamanya. Struktur yang populistik adalah manifestasi kehidupannya dan kebulatan kerangka pemikiran sebagai resep utamanya. Hanafi sampai pada kesimpulan bahwa Islam sebaiknya berfungsi orientatif bagi ideologi populistik yang ada.

Pada akhir periode ini, dan berlanjut hingga awal periode 1970-an, Hanafi juga memberikan perhatian utamanya untuk mencari penyebab kekalahan umat Islam dalam perang melawan Israel tahun 1967. Oleh karena itu, tulisan-tulisannya lebih bersifat populis. Di awal periode 1970an, ia banyak menulis artikel di berbagai media massa, seperti al Katib, al-Adab, alFikr al-Mu'ashir, dan Mimbar al-Islam. Pada tahun 1976, tulisan-tulisan itu diterbitkan sebagai sebuah buku dengan judul Qadhâyâ Mu'âshirah fi Fikrina al-Mu'âshir. Buku ini memberikan deskripsi tentang realitas dunia Arab saat itu, analisis tentang tugas para pemikir dalam menanggapi problema umat, dan tentang pentingnya pembaruan pemikiran Islam untuk menghidupkan kembali khazanah tradisional Islam. Kemudian, pada tahun 1977, kembali ia menerbitkan Qadhaya $\mathrm{Mu}$ 'ashirat fi al Fikr al-Gharb. Buku kedua ini mendiskusikan pemikiran para sarjana Barat untuk melihat bagaimana mereka memahami persoalan masyarakatnya dan kemudian mengadakan pembaruan.

Beberapa pemikir Barat yang ia singgung itu antara lain Spinoza, Voltaire, Kant, Hegel, Unamuno, Karl Jaspers, Karl Marx, Marx Weber, Edmund Husserl, dan Herbert Marcuse. Kedua buku itu secara keseluruhan merangkum dua pokok pendekatan analisis yang berkaitan dengan sebabsebab kekalahan umat Islam; memahami posisi umat lslam sendiri yang lemah, dan memahami posisi Barat yang superior. Untuk yang pertama penekanan diberikan pada upaya pemberdayaan umat, terutama dari segi pola pikirnya, dan bagi yang kedua ia berusaha untuk menunjukkan bagaimana menekan superioritas Barat dalam segala aspek kehidupan. Kedua pendekatan inilah yang nantinya melahirkan dua pokok pemikiran baru yang tertuang dalam dua buah karyanya, yaitu al-Turats wa al-Tajdid (Tradisi dan Pembaruan), dan al-Istighrab (Oksidentalisme).

Pada periode ini, yaitu antara tahun-tahun 1971-1975, Hanafi juga menganalisis sebabsebab ketegangan antara berbagai kelompok kepentingan di Mesir, terutama antara kekuatan Islam radikal dengan pemerintah. Pada saat yang sama situasi politik Mesir mengalami ketidakstabilan yang ditandai dengan beberapa peristiwa penting yang berkaitan dengan sikap Anwar Sadat yang pro-Barat dan memberikan kelonggaran pada Israel, hingga ia terbunuh pada Oktober 1981. Keadaan itu membawa Hanafi pada pemikiran bahwa seorang ilmuan juga harus mempunyai tanggung jawab politik terhadap nasib bangsanya. Untuk itulah kemudian ia menulis al-Din wa al-Tsaurah $f i$ Mishr 1952-1981. Karya ini terdiri dari 8 jilid yang merupakan himpunan berbagai artikel yang ditulis antara tahun 1976 sampai 1981 dan diterbitkan pertama kali pada tahun 1987. Karya itu berisi pembicaraan dan analisis tentang kebudayaan nasional dan hubungannya dengan agama, hubungan antara agama dengan perkembangan nasionalisme, tentang gagasan mengenai gerakan 'Kiri Keagamaan' yang membahas gerakan-gerakan keagamaan kontemporer, fundamentalisme Islam, serta 'Kiri Islam dan Integritas Nasional'. Dalam analisisnya Hanafi menemukan bahwa salah satu penyebab utama konflik berkepanjangan di Mesir adalah tarik-menarik antara ideologi Islam barat dan ideologi sosialisme. Ia juga memberikan bukti-bukti penyebab munculnya berbagai tragedi politik dan menganalisis penyebab munculnya radikalisme Islam.

Karya-karya lain yang ia tulis pada periode ini adalah Religious Dialogue and Revolution dan Dirasat al-Islamiyyah. Buku pertama berisi pikiran-pikiran yang ditulisnya antara tahun 1972-1976 ketika ia berada di 
Amerika Serikat, dan terbit pertama kali pada tahun 1977. Pada bagian pertama bu$\mathrm{ku}$ ini ia merekomendasikan metode hermeneutika sebagai metode dialog antara Islam, Kristen, dan Yahudi. Sedangkan bagian kedua secara khusus membicarakan hubungan antara agama dengan revolusi, dan lagi-lagi ia menawarkan fenomenologi sebagai metode untuk menyikapi dan menafsirkan realitas umat Islam. Sementara itu Dirâsât Islâmiyyah, yang ditulis sejak tahun 1978 dan terbit tahun 1981, memuat deskripsi dan analisis pembaruan terhadap ilmu-ilmu keislaman klasik, seperti ushul fikih, ilmu-ilmu ushuluddin, dan filsafat. Dimulai dengan pendekatan historis untuk melihat perkembangannya, Hanafi berbicara tentang upaya rekonstruksi atas ilmu-ilmu tersebut untuk disesuaikan dengari realitas kontemporer.

Periode selanjutnya, yaitu dasawarsa 1980-an sampai dengan awal 1990-an, dilatarbelakangi oleh kondisi politik yang relatif lebih stabil ketimbang masa-masa sebelumnya. Dalam periode ini, Hanafi mulai menulis al-Turâts wa al-Tajdîd yang terbit pertama kali tahun 1980. Buku ini merupakan landasan teoritis yang memuat dasar-dasar ide pembaharuan dan langkahlangkahnya. Kemudian, ia menulis al- Yasâr al-lslamiy (kiri Islam), sebuah tulisan yang lebih merupakan sebuah "manifesto politik" yang berbau ideologis, sebagaimana telah saya kemukakan secara singkat di atas.

Jika kiri Islam baru merupakan pokokpokok pikiran yang belum memberikan rincian dari program pembaruannya, buku Min Al-Aqidah ila Al-Tsaurah (5 jilid), yang ditulisnya selama hampir sepuluh tahun dan baru terbit pada tahun 1988. Buku ini memuat uraian terperinci tentang pokok-pokok pembaruan yang ia canangkan dan termuat dalam kedua karyanya yang terdahulu. Oleh karena itu, bukan tanpa alasan jika buku ini dikatakan sebagai karya Hanafi yang paling monumental.

Satu bagian pokok bahasan yang sangat penting dari buku ini adalah gagasan rekonstruksi ilmu kalam. Pertama-tama ia mencoba menjelaskan seluruh karya dan aliran ilmu kalam, baik dari sisi kemunculannya, aspek isi dan metodologi maupun perkembangannya. Lalu ia melakukan analisis untuk melihat kelebihan dan kekurangannya, terutama relevansinya dengan konteks modernitas. Salah satu kesimpulannya adalah bahwa pemikiran kalam klasik masih sangat teoretis, elitis dan statis secara konsepsional. Ia merekomendasikan sebuah teologi atau ilmu kalam yang antroposentris, populis, dan transformatif.

Selanjutnya, pada tahun-tahun 19851987, Hanafi menulis banyak artikel yang ia presentasikan dalam berbagai seminar di beberapa negara, seperti Amerika Serikat, Perancis, Belanda, Timor Tengah, Jepang, termasuk Indonesia. Kumpulan tulisan itu kemudian disusun menjadi sebuah buku yang berjudul Religion, Ideology, and Development yang terbit pada tahun 1993. Beberapa artikel lainnya juga tersusun menjadi buku dan diberi judul Islam in the Modern World (2 jilid). Selain berisi kajian-kajian agama dan filsafat, dalam karya-karyanya yang terakhir pemikiran Hanafi juga berisi kajian-kajian ilmu sosial, seperti ekonomi dan teknologi. Fokus pemikiran Hanafi pada karya karya terakhir ini lebih tertuju pada upaya untuk meletakkan posisi agama serta fungsinya dalam pembangunan di negaranegara dunia ketiga.

Pada perkembangan selanjutnya, Hanafi tidak lagi berbicara tentang ideologi tertentu melainkan tentang paradigma baru yang sesuai dengan ajaran Islam sendiri maupun kebutuhan hakiki kaum muslimin. Sublimasi pemikiran dalam diri Hanafi ini antara lain didorong oleh maraknya wacana nasionalisme-pragmatik Anwar Sadat yang menggeser popularitas paham sosialisme Nasser di Mesir pada dasawarsa 1970-an. Paradigma baru ini ia kembangkan sejak paroh kedua dasawarsa 1980-an hingga sekarang.

Pandangan universalistik ini di satu si- 
si ditopang oleh upaya pengintegrasian wawasan keislaman dari kehidupan kaum muslimin ke dalam upaya penegakan martabat manusia melalui pencapaian otonomi individual bagi warga masyarakat; penegakan kedaulatan hukum, penghargaan padaHAM, dan penguatan (empowerment) bagi kekuatan massa rakyat jelata. Pada sisi lain, paradigma universalistik yang diinginkan Hanafi harus dimulai dari pengembangan epistemologi ilmu pengetahuan baru. Orang Islam, menurut Hanafi, tidak butuh hanya sekadar menerima dan mengambil alih paradigma ilmu pengetahuan modern Barat yang bertumpu pada materialisme, melainkan juga harus mengikis habis penolakan mereka terhadap peradaban ilmu pengetahuan Arab. Seleksi dan dialog konstruktif dengan peradaban barat itu dibutuhkan untuk mengenal dunia barat dengan setepat-tepatnya. Dan upaya pengenalan itu sebagai unit kajian ilmiah, berbentuk ajakan kepada ilmu-ilmu kebaratan (al-Istighrab, oksidentalisme) sebagai imbangan bagi ilmu-ilmu ketimuran (al-Istisyraq, orientalisme). Oksidentalisme dimaksudkan untuk mengetahui peradaban Barat sebagaimana adanya, sehingga dari pendekatan ini akan muncul kemampuan mengembangkan kebijakan yang diperlukan kaum muslimin dalam ukuran jangka panjang. Dengan pandangan ini Hassan Hanafi memberikan harapan Islam untuk menjadi mitra bagi peradaban-peradaban lain dalam penciptaan peradaban dunia baru dan universal.

\section{Proyek al-Turâts wa al-Tajdîd}

Pemikiran Hasan Hanafi tentang ilmu ushul fiqih tidak lepas dari tema besar perjuangan pembaruan ilmu-ilmu Islam yang dia canangkan. Tema besar pembaruan tersebut populer dengan sebutan proyek alturâts wa al-tajdìd (tradisi dan pembaruan). Tujuan yang hendak dibidik dari proyek tersebut adalah: 1) mencari solusi metodologi (manhaj) kajian terhadap turats (tradisi) Islam klasik, dan 2) memerankan turats secara optimal untuk membangun kehidupan yang cemerlang di masa mendatang. al-Turâts wa al-Tajdî̀ adalah slogan untuk al-ashalâh (mempertahankan otensitas) sekaligus pada saat yang sama meraih kemodernan (al-hadâtsah). Cita-cita itu belum terwujud secara sempurna. Pembaruan terhadap turats penting dilakukan sebab perang di era sekarang bukan hanya perang militer. Perang sesungguhnya adalah perang pemikiran, kebudayaan dan ekonomi. Kekalahan juga demikian; tidak hanya kekalahan militer, melainkan kekalahan intelektualitas (pemikiran). Ancaman kita bukan hanya berupa hilangnya wilayah perbatasan negara, tetapi juga ancaman akan hilangnya semangat hidup dan berjuang ${ }^{7}$

Untuk melaksanakan proyek al-turâts wa al-tajdîd diperlukan tiga langkah yang saling berurutan. Pertama, umat Islam harus mengetahui posisi dirinya ketika ia berhadapan dengan tradisi atau khazanah intelektual klasik miliknya sendiri. Kedua, umat Islam harus mengetahui posisinya ketika berhadapan dengan tradisi (khazanah intelektual) Barat (Eropa). Ketiga, penguasaan dan ketepatan dalam melakukan interpretasi (nadhriyat al-tafsîr).

Untuk menyukseskan pelaksanaan langkah pertama, Hasan Hanafi menulis tujuh kitab sebagai panduan dan pemberi arah akan diorientasikan kemana kajian islam kita?. Dalam bidang teologi (ushîl al-dîn), ia menulis Min al-'Aqîdah ilâ al-Tsawrah ${ }^{8}$ sebanyak lima jilid tebal. Dalam bidang filsafat, ia menulis Min al-Naql ilâ al-Ibdâ'. Dalam bidang metodologi ushul fiqih, ia menulis Min al-Nash ila al-Waqi'. Dalam bidang tasawwuf, ia menulis Min al-Fana' ila al-Baqa'. Dalam ilmu-ilmu naqli selain kalam, tasawwuf, filsafat, dan ushul fiqih, seperti ulumul Qur'an, hadis, tafsir, sejarah dan fiqih, ia menulis Min al-'Aql ilâ al-Naql. Dalam

${ }^{7}$ Hasan Hanafi, al-Turâts wa al-Tajdîd, h. 176

${ }^{8}$ Hasan Hanafi, Min al-'Aqî́dah ilâ al-Tsawrah (Beirut: Dar al-Tanwir, 1988). Volume I membahas tentang almuqaddimah al-nadhriyah. Volume kedua tentang al-Insan al-Kamil; al-tawhid. Volume ketiga tentang al-Insan al-Kamil: al-'adl.Volume keempat tentang alTarikh al-`Amm, dan volume kelima tentang al-Tarikh al-Mu'ayyan. 
bidang ilmu alam dan eksakta, ia menulis al-Wahy wa al-'Aql wa al-Tabi'iyah. Dalam bidang ilmu jiwa, sosial, politik, geografi dan bahasa serta sastra, Hanafi menulis al-Insân wa al-Târikh.

Setelah sukses menata ulang dan merekonstruksi diri, maka umat Islam perlu melakukan langkah tindak lanjut pembaruan, yaitu memahami posisi umat Islam di hadapan kekuatan tradisi (khazanah intelektual) bangsa-bangsa Eropa. Langka kedua ini adalah langkah yang wajar. Juga tidak perlu diributkan sebab sebenarnya langkah ini pernah dilakukan umat Islam era dinasti Abbasiyah. Sebelum Islam mencapai masa keemasannnya di era Abbassiyah, terlebih dahulu Islam berhadapan dengan kebudayaan Yunani. Sekarang berbeda yang dihadapi yaitu bangsa Eropa.

Sebagai arah dan orientasi dalam langkah kedua ini, Hasan Hanafi menulis enam buku. Pertama, 'Ashr Âbâ' al-Kanâ'is: Mashâdir alWa'y al-Uruby (Masa Para Tokoh Gereja: Sumber Kesadaran Eropa), kedua, ia menulis al-Ashral-Madrasiy:Mashâdiral-Wa'yal-Uruby, (Masa Skolastik: Sumber Kesadaran Eropa). Ketiga, al-Ishlâh al-Dîny wa 'Ashr al-Nahdlah: Nihâyat al-Wa'y al-Uruby (Reformasi Agama di Masa Kebangkitan: Puncak Kesadaran Eropa). Karya-karya tentang Eropa di atas diulas untuk memberi informasi kepada kita tentang sumber kekuatan dan kebangkitan Eropa agar diambil secara selektif oleh umat Islam untuk meraih kebangkitan yang dahulu pernah hilang dari tangan mereka.

Jika langkah pertama dan kedua telah ditempuh maka langkah ketiga yaitu nadhriyat al-tafsîr (teori-teori interpretasi) sebagai langkah puncak. Langkah ketiga ini adalah titik finish yang hendak dicapai oleh proyek al-turâts wa al-tajdîd adalah upaya untuk merekonstruksi peradaban Islam dengan berpijak kepada semangat wahyu dan cara-cara menginterpretasikannya. Wahyu diinterpretasikan sehingga memberi kontribusi bagi munculnya ilmu-ilmu kemanusiaan universal (al-'ilm al-insani al-syâmil).
Untuk mensukseskan langkah ketiga ini, Hasan Hanafi menulia tiga literature yaitu al'Ahd al Qadîm, al-'Ahd al-Jadîd dan al-Minhaj.'

Dari peta proyek yang diusung oleh Hasan Hanafi di atas dapat kita ketahui bahwa ilmu ushul fiqih yang akan diperkenalkan dalam tulisan ini adalah secuil dari bidang garap pembaharuan Hasan Hanafi. Juga tampak kepada kita bahwa Hasan Hanafi adalah intelektual multidisiplin ilmu pengetahuan. Ia ingin menjadi seperti para ulama multidisipliner kebanggaan Islam di masa lalu seperti al-Ghazali, Ibnu Taymiyah, Ibnu Hazm dan Ibnu Sina. Al-Ghazali bukanlah seorang ahli kalam saja, filosof saja. Ahli ushul fiqih saja atau ahli kalam saja. Al-Ghazali adalah mutakkalim, sufi, ushuli dan filosuf. Ibnu Sina adalah filosof dan tabib sekaligus. ${ }^{10}$

\section{Rekonstruksi Ilmu Ushul Fiqih}

Ada dua alasan yang menyebabkan Hasan Hanafi menulis ushul fiqih yang dari tulisannya itu tampak upaya kerasnya untuk melakukan rekonstruksi terhadap ilmu ushul fiqih (i'âdat binâ 'ilm ushûl figh). Alasan pertama adalah alasan keprihatinan atas persepsi sejarah ${ }^{11}$ dan yang kedua adalah karena ingin lebih mentransparankan dan memprioritaskan manusia dalam berperan 'menyambut' misi wahyu dalam realitas kehidupannya di dunia sehingga tercipta mashlahah yang universal. ${ }^{12}$

Terkait alasan pertama, Hasan Hanafi sangat tidak setuju bila ada orientalis yang berpersepsi bahwa filsafat Islam secara otentik-

\footnotetext{
${ }^{9}$ Hasan Hanafi, al-Turâts wa al-Tajdîd, h. 180-185

${ }^{10}$ Hasan Hanafi, al-Turâts wa al-Tajdîd, h.173

${ }^{11}$ Data yang disajikan tentang alasan pertama (keprihatinan Hasan Hanafi terhadap mispersepsi orientalis atas filsafat Islam dalam makalah ini dapat dibaca dalam Hasan Hanafi, Min al-Nash ilâ al-Wâqi' Juz I: Takwîn al-Nash (Cairo: Markaz al-Kitab li al-Nasyr, 2004), h. 6-9.

${ }^{12}$ Alasan kedua, keprihatinan Hasan Hanafi tentang kurang transparan dan kurang menjadikan manusia sebagai subjek utama kajian ilmu naqli-rasional Islam klasik dapat dibaca dalam bab "limâdzâ Ghâba Mabhas al-Insân fi Turâtsina al-Qadîm" dalam Hasan Hanafi, Dirâsât Islâmiyah (Cairo: Maktabat al-Anjlâ alMishriyah,1981), hal. 393- 415.
} 
itu tidak ada. Filsafat Islam hanyalah 'foto copi' dari filsafat Yunani, yang ada dalam filsafat Islam hanyalah terjemahan, ringkasan dan komentar terhadap filsafat Yunani.

Tokoh yang menginspirasi Hasan Hanafi untuk menolak persepsi orientalis tersebut adalah al-Syeikh Mustofâ 'Abd al-Razzaq dan muridnya yaitu Syâmi al-Nasysyâr. Mustafa 'Abd al-Razzaq, murid Muhammad 'Abduh, menulis karya yang sangat populer yaitu al-Tamhid li Tarikh al-Falsafah fi al-Islam (Pengantar Sejarah Filsafat Islam). Karya itu ditulis untuk menolak pandangan orientalis tentang tidak adanya orisinalitas dalam filsafat Islam. Dengan bukunya itu, Mustafa 'Abd al-Razzaq ingin menandaskan bahwa umat Islam mampu berfilsafat sendiri. Hasilnya adalah berupa ilmu ushul fiqih. Filsafat Islam yang otentik adalah ilmu ushul fiqih. Karya Mustafa 'Abd al-Razzaq kemudian dielaborasi oleh Syami al-Nasysyar. Sang murid menulis kitab berjudul Manahij al-Bahs 'Inda Mufakkir al-Islam wa Naqd al-Muslimin li Manthiq al-Aristhathilisi (Metodologi Pembahasan Pemikir Islam dan Kritik Mereka terhadap Logika Aristoteles).

Bersamaan dengan terbitnya dua kitab itu muncul gerakan reformasi modern (harakah al-ishlah al-hadîts) pasca diresmikannya konsentrasi filsafat di Universitas al-Mishriyah, gerakan berjalan lancar dan semakin mantap. Akibatnya, di perguruan tinggi pada konsentrasi filsafat dimasukkan ushul fiqih sebagai mata kuliah resmi. Kajian Islam rasional klasik yang awalnya adalah kalam, tasawwuf dan filsafat bertambah satu yaitu ushul fiqih. Karya al-Syatibi seperti al-Muwafaqât fi Ushûl al-Syarîah diajarkan.

Hasan Hanafi yang sebelumnya sudah berupaya keras melakukan rekonstruksi terhadap tiga keilmuan wahyu-rasional (naqliyah-'aqliyah) seperti rekonstruksi ilmu ushuluddin melalui karyanya Min al-'Aqîdah ilâ al-Tsawrah lima jilid, rekonstruksi ilmu hikmah melalui karyanya yaitu Min al-Naql ilâ al-Ibdâ', dan rekonstruksi ilmu tasawwuf melalui karyanya Min al-Fanâ' ilâ al-Baqấ' ter- motivasi untuk melakukan hal yang serupa kepada ilmu ushul fikih.

Oleh karena itu, ia menulis rekonstruksi ilmu ushul fiqih dengan karyanya yaitu Min al-Nash ilâ al-Wâqi'. Karya ushul fiqih Hasan Hanafi ini terdiri atas dua jilid. Min al-Nash ilâ al-Wâqi' jilid pertama bersub judul Takwîn alNash berisi tentang kumpulan literatur ushul fiqih para ulama ushul fiqih dari berbagai madzhab. Min al-Nash ilâ al-Wâqi' jilid dua bersub judul Binyat al-Nash ${ }^{13}$ berisi teori-teori ushul fiqih sesuai pemikiran Hasan Hanafi seperti pembahasan tentang al-Qur'an, sunnah, ijma', qiyas, teori-teori penafsiran terhadap lafadz, dan makna redaksi wahyu seperti teori majâz, hakîkat, mujmal, mutlaq, 'âm-khâsh, nasakh-mansukh, dan tentang ahkâm syar'iyah.

Judul Min al-Nash ilâ al-Wâqi' ditulis untuk mengekspresikan maksud penulisnya, yaitu; teks atau huruf, terutama teks wahyu harus bertransformasi mendatangkan mashlahah yang dinamis seiring perkembangan zaman dan wilayah. Kata al-nash berari teks, sedangkan kata al-waqi' berarti mashlahah. Diharapkan dengan karya ini ahli fiqih menjadi piawai ber-istidlâl, mengunggulkan mashlahah 'âmmah -dalam proses tasyrî'untuk mengalahkan tekstualitas wahyu. Memprioritaskan realitas daripada nash. Dengan karya di atas, Hasan Hanafi juga ingin menepis persepsi bahwa tasyrî́ dalam Islam itu hanya fiqih tekstualis, bengis, mengorbankan mashlahah atau yang dikenal dalam syariat Islam hanya hukum bunuh, rajam, jilid, potong tangan, salib dan hukumhukum yang berada diluar batas kemampuan manusia.

Bagi Hanafi, ilmu ushul fiqih ilmu tentang cara meng-istimbâth hukum-hukum syariat Islam dari dalil-dalil ijmali dalam wahyu, bukan dalil tafshili yang menjadi garapan fiqih- merupakan ilmu tanzîl; ilmu yang berasal dari Allah yang ada 'di atas' diturunkan kepada manusia yang ada 'di

${ }^{13}$ Hasan Hanafi, Min al-Nash ilâ al-Wâqi' Juz II : Binyat al-Nash (Cairo: Markaz al-Kitâb li al-Nasyr, 2004) 
bawah.' Ilmu ushul fiqih adalah ilmu yang berorientasi ke bawah (manusia). Dari Allah untuk mashlahah manusia. Berbeda dengan ilmu tasawwuf yang menjadi ilmu ta'wil', dari bawah (manusia) menuju ke atas (Allah). Dengan demikian, ilmu tasawuf berorientasi 'ke atas', kembalinya manusia kepada Tuhan. ${ }^{14}$

Untuk pertama kali, ilmu ini diciptakan oleh al-Imam al-Syafii (204 H) melalui kitab yang ditulisnya yaitu al-Risâlah. Kemudian muncul beberapa ulama klasik yang menulis tentang ushul fiqih dari berbagai madzhab seperti Abu Hasan al-Bahsri $(430 \mathrm{H})$ yang menulis al-Mu'tamad fi Ushûl al-Figh. AlJuwayni $(478 \mathrm{H})$ menulis dua kitab yaitu alBurhân dan al-Waraqât. Al-Ghazali $(505 \mathrm{H})$ menulis al-Mustashfâ. Ibnu al-Qayyim (751 H) menulis I'lam al-Muwaqi'în. Al-Syathibi $(790 \mathrm{H})$ menulis al-Muwâfaqât fî Ushûl alSyarî'ah, dipamungkasi oleh al-Syawkani $(1255 \mathrm{H})$ dengan kitab Irsyâd al-Fukhûl. Setelah itu, muncul karangan tentang ushul fiqih pada tema-temanya yang spesifik seperti tentang ijma' saja seperti karya Ibnu Taymiyah berjudul Naqd Marâtib al-Ijma', dan tentang Qiyas seperti karya Ibnu alQayyim berjudul al-Qiyâs fi al-Syar'i al-Islami. Kemudian, muncul karya-karya tentang ushul fiqih yang bercorak akademis di berbagai perguruan tinggi seperti yang telah ditulis Hasan Hanafi dalam bahasa Prancis pada 1965 M/1385 H yaitu Les Methodes de la Comprehension, Elm Usul al-Figh diterbitkan di Kairo tahun 1965.

Ushul Fiqih Hasan Hanafi berbeda dengan literatur-literatur ushul fiqih pada umumnya seperti ushul fiqih al-Ghazali, Wahbah al-Zuhayli dan 'Abd al-Wahhab Khallaf. Titik perbedaan itu minimal terlihat pada tiga isi berikut ini: Pertama, urutan tema pembahasan. Pembahasan ushul fiqih pada umumnya dimulai dari empat poin; (1) tentang hukum-hukum syara' baik yang wadh'iy maupun takliffiy. (2) tentang al-adillah al-syar'iyah. (3) tentang cara-cara ber-istidlâl, dan (4) tentang ijtihad, taqlid dan persoalan

${ }^{14}$ Hanafi, Dirâsât Islâmiyah, hal 103 yang serangkaian dengannya. Hasan Hanafi menolak sistematika pembahasan seperti itu karena tidak tepat dan tidak sinkron secara fungsi. Adapun yang tepat dan sinkron menurutnya adalah; a) al-adillah al-syar'iyyah (yang berupa wahyu Qur'an dan sunnah) lebih utama untuk diletakkan di posisi awal atau sebagai titik start. b) pembahasan tentang cara-cara istidlâl diletakkan pada posisi tengah.c) pembahasan tentang hukumhukum syara' diletakkan di posisi terakhir atau finish. Dalil-dalil wahyu adalah bahan atau sumber 'produksi' hukum. Cara-cara istidlâl ibarat cara, kiat, tips, dan metodologi untuk berproduksi. Sedangkan al-ahkam alsyar'iyah adalah seperti hasil produksi.

Kedua, kecenderungan dan orientasi. Umumnya literatur ushul fiqih dalam mengartikulasikan meaning dalam pembahasannya diletakkan berada di balik posisi Tuhan sehingga posisi manusia tidak menjadi posisi kunci atau tidak 'transparan'. Hal yang demikian itu ingin diubah oleh Hasan Hanafi. Ia ingin lebih mentransparankan dan memprioritaskan manusia dalam berperan 'menyambut' misi wahyu dalam realitas kehidupannya. Itu dilakukan sebagai konsekwensi dari kritik tajamnya atas turats klasik dalam sub-pembahasannya dalam Dirasat Islamiyah yaitu sub pembahasan Limâdzâ Ghâba Mabhas al-Insân fî Turâtsina alQadîm?

Ketiga, sarat ungkapan potensi manusia. Akibat dari kecenderungan dan orientasi pada nomor dua di atas, maka ushul fiqih Hasan Hanafi sarat dengan ideom-ideom potensi kemanusiaan. Ketika membahas almashâdir al-arba'ah untuk syari'at (Qur'an, sunnah, ijma', ijtihad/qiyas), Hasan Hanafi menyebut empat mashadir tersebut dengan ungkapan al-syu'ûr al-târîkhit ${ }^{15}$ (sense kesejarahan). Fakta yang menjamin bahwa nashnash wahyu itu terjaga orisinalitas dan validitasnya dalam sejarah hidup manusia. Ketika mencantumkan pembahasan tentang al-Qur'an pada pasal pertama, Hanafi menuliskan kata "al-tajribah al-Insâniyah al-'âmmah/

${ }^{15}$ Hanafi, Dirâsât..,h. 69 
eksperimen kemanusiaan yang universal di atas kata al-kitab. ${ }^{16}$ Al-Sunnah diungkapkan dengan istilah al-tajribah al-namûdzajiyyah (eksperimen percontohan $)^{17}$. Ijma' diungkapkan dengan istilah al-tajrîbiyyah al-musytarakah (eksperimen komunal) ${ }^{18}$, dan ijtihad atau qiyas diungkapkan dengan istilah al-tajrîbiyyah al-fardiyah (eksperimen individual $)^{19}$. Pembahasan tentang cara beristidlal dan content redaksi wahyu yang dieksplorasi seperti pembahasan tentang lafad, makna, dan 'illat diungkapkan dengan istilah al-syu'ûr al-ta'ammuliy (sense perenungan). Sedangkan pembahasan tentang macam-macam hukum (wadl'i-taklîfi) diungkapkan dengan istilah al-syu'ûr al'amaliy (sense praktis, sisi praktis dalam hukum). ${ }^{204}$ ). Bersifat deduktif. Dalam Min al-Nash ilâ al-Wâqi' sangat 'sepi' dijumpai adanya contoh-contoh hukum seperti ketika membahas tentang 'âm-khâsh, hakikat-majaz, nasakh-mansukh, hukum taklifi seperti wajib, sunnah, mubah, makruh dan haram tanpa menyebutkan contoh. Tampaknya Hasan Hanafi ingin menjadikan teori ushul fiqih-nya sebagai teori yang bersifat deduktif, yang berisi teori-teori umum saja.

\section{Kesimpulan}

Kajian Islam, termasuk ushul fiqih di dalamnya, tengah mengalami kemandegan di beberapa cabang keilmuannya. Munculnya tokoh-tokoh yang mencoba memberi 'sentuhan' baru dalam paradigma dan metodologi untuk mengembangakan secara ilmiah dan bertanggung jawab kajian Islam itu perlu diapresiasi. Cendekiawan seperti Hasan Hanafi, Muhammad Abed al-Jabiri, M. Quraish Shihab dan Hamka adalah contoh dari orang yang mencoba memberi sentuhan baru tersebut.

\footnotetext{
${ }^{16}$ Hanafi, Min al-Nash ilâ al-Waqi', h. 99

${ }^{17}$ Ibid. 139

${ }^{18}$ Ibid, 191

${ }^{19}$ Ibid. 215

${ }^{20}$ Hanafi, Dirâsât.., h.78 dan 94
}

Hasan Hanafi sangat konsentrasi dengan proyek pembaharuan tradisi (turâts) Islam yang dikemasnya dalam slogan al-turâts wa al-tajdîd. Dalam mengimplementasikan al-turâts wa al-tajdîd ditempuh tiga langkah umum yaitu 1) Menelaah tradisi klasik kita untuk mencari bagaimana kita bersikap dan berposisi terhadap tradisi klasik kita (mawqifunâ min al-turâts al-qadîm), 2) menelaah tradisi Barat untuk mengetahui bagaimana kita bersikap dan berposisi dalam tradisi Barat tersebut (mawqifunâ min al-turâts al-gharby, dan 3) melakukan interpretasi-interpretasi (nadhriyyât al-tafsîr).

Rekonstruksi ushul fiqih adalah salah satu cabang dari proyek pembaharuan tradisi Hasan Hanafi. Baginya, ushul fiqih adalah ilmu 'tanzîl'; yaitu 'sesuatu' yang berasal dari Allah untuk manusia. Ilmu yang berorientasi ke bawah, kepada mashlahah manusia.

Ushul fiqih yang dicoba oleh Hasan Hanafi untuk direkonstruksi minimal tampak perbedaannya dengan ushul fiqih karya para ushuli terdahulu pada empat aspek: Pertama, resistematisasi objek pembahasan. Dimulai dari al-mashâdir al-arba'ah, lalu al-adillah alsyar'iyyah kemudian al-ahkâm al-syar'iyah. Tiga urutan tersebut sistematis dan secara fungsional saling menunjang. Kedua, adanya orientasi dan kecenderungan memberi ruang lebar bagi pentransparanan bagi tugas dan potensi manusia dalam menjemput misi wahyu dan pengimplementasiannya dalam kehidupan manusia yang riil. Ketiga, memberikan idiom-idiom (redaksi, ta'bîr) yangmengartikulasikan potensikemanusiaan sebagai tindak lanjut dari kesimpulan nomor dua di atas. Keempat, bersifat deduktif, menjelaskan teori-teori yang bersifat general dan sepi dari penyebutan contoh-contoh hukum sebagai deskripsi bagi teori-teori pemahaman terhadap isi teks seperti contoh nash yang termansukh, tersepesialisasikan (tahshish) dan lain-lain. 


\section{DAFTAR PUSTAKA}

Abdalla, Ulil Abshar. 2006. Kenapa Kajian Islam Mandeg? (www.islamlib.com. Diakses 30 Mei 2006).

An-Naim, Abdullah Ahmed. 1946. Toward an Islamic Reformation: Civil Liberties, Human Right and International Law. New York: Syracuse University Press.

Averroes. 1996. Le Livre Du Discours Decisif . Paris: Flammarion

Hanafi, Hasan. 1992. Al-Turats wa al-Tajdid. Beirut: al-Muassasah al-Jami'ah li alDirasat wa al-Nasyr wa al-Tawzi'.

Hanafi, Hasan. t.t. Dirasat Islamiyah. Cairo: Maktabat al-Injla al-Mishriyah

Hanafi, Hasan. 2004. Min al-Nash ila al-Waqi'
Juz I : Takwin al-Nash. Cairo: Markaz al-Kitab li al-Nasyr.

Hanafi, Hasan. 2004. Min al-Nash ila al-Waqi' Juz II: Binyat al-Nash. Cairo: Markaz al-Kitab li al-Nasyr.

Hanafi, Hasan. 1988. Min al-'Aqidah ila alTsawrah. Beirut: Dar al-Tanwir.

Madjid, Nurcholish. t.t. Khazanah Intelektual Islam. Bandung: Bulan Bintang.

Hasan, Ridwan Ahmad. Pemikiran Hasan Hanafi: Studi Historis Kritis Gagasan Reaktualisasi Tradisi Keilmuan. (http://en.wikipedia.org/ wiki/Hasan_Hanafi, 1997). 